\title{
PEMBERDAYAAN MASYARAKAT MELALUI BIDANG LITERASI DI DESAWARU JAYA
}

\author{
Fenti Dewi Pertiwi ${ }^{1}$, Ripki Mulia Rahman, Denisa Dwi Lestari ${ }^{2}$ \\ fenti@uika -bogor.ac.id \\ Dosen Fakultas Ilmu Kesehatan ${ }^{1}$, Mahasiswa KKN Kelompok 19 Tahun $2017^{2}$
}

\begin{abstract}
ABSTRAK
literasi berasal dari bahasa latin yaitu literatur dan bahasa Inggris Letter. Literasi merupakan kemampuan melek baca dan tulis. Membaca merupakan hal yang sangat penting dalam kehidupan manusia sebagaimana perintah Alquran yaitu "iqra" bacalah. Tidak hanya membaca sebuah tulisan akan tetapi membaca ide, gagasan dan masalah yang terjadi di masyarakat untuk mendapatkan solusi yang tepat. Saat ini, literasi di masyarakat Indonesia masih dikatakan rendah dengan frekuensi interaksi dengan buku yang sangat minim. Hal ini lah yang menjadi sebuah gerakan baru untuk meningkatkan pengetahuan masyarakat dalam berbagai bidang keilmuan. Literasi banyak macam nya seperti literasi informasi dan literasi teknologi. Pemahaman akan literasi yang bermacam-macam menjadikan literasi sebuah hal yang kompleks yang bisa dilihat dari berbagai sudut pandang. Namun secara garis besar literasi merupakan sebuah media dalam menambah wawasan keilmuan di masyarakat. Metode pendekatan yang digunakan dalam kegiatan ini adalah: (1) Pendekatan religius; (2) Pendekatan organisasi; (3) Pendekatan kekerabatan; Hasil yang dicapai adalah masyarakat lebih tertarik dengan kegiatan literasi secara harfiah yaitu dengan selalu mencari informasi dengan membaca baik di media cetak seperti koran dan buku. Dan secara maknawi masyarakat lebih bisa membaca keadaan yang ada disekitarnya untuk bisa menciptakan ide, gagasan dan solusi yang dihadapi di masyarakat. Gerakan literasi ini sejalan dengan gerakan keaksaraan fungsional yaitu sebuah gerakan pengentasan buta huruf untuk bisa meningkatkan taraf hidup masyarakat dan meningkatkan kemampuan masyarakat dalam berkomunikasi.
\end{abstract}

Kata Kunci : Baca Tulis, Literasi, Melek Aksara.

\section{PENDAHULUAN}

Lokasi pelaksanaan kegiatan Kuliah Kerja Nyata Universitas Ibn Khaldun Kelompok 19 berada di Kecamatan Parung Kabupaten Bogor. Tepatnya di desa Waru Jaya Dusun II RW 2. Secara umum wilayah pelaksanaan kegiatan berada di RW 2 yang terdiri dari 4 RT yaitu RT 01, RT 02, RT 07 dan RT 08. Namun pusat kegiatan berada di RT 02 yang juga sekaligus sebagai lokasi posko kegiatan.
Sudah menjadi aturan baku dari di lingkungan RW 02 untuk melaksanakan semua kegiatan masyarakat dalam lingkup satu RW sehingga semua RT yang berada di bawah RW 02 menjadi satu kesatuan kecuali RT 07 yang notabene nya adalah para pendatang yang tinggal di perumahan. Mayoritas masyarakat lingkungan RW 02 bekerja sebagai buruh lepas yang bekerja baik di wilayah Bogor maupun Jakarta. Adapun lingkungan pemukiman terpadat 
berada di RT 02 dengan total lebih dari 200 KK.

Pemuda lingkungan RW 02 aktif di lembaga kemasyarakatan seperti IPPMI (Ikatan Pengajian Pemuda Masjid AlIstiqomah), Karang Taruna, dan PPID (Persatuan Pemuda Islam Desa Waru Jaya). Adapun ibu-ibu aktif di kegiatan PKK dan bapak-bapak yang aktif mengikuti pengajian setiap malam Jum'at.

Program KKN bukanlah hal yang baru di lingkungan RW 02 karena sudah ada beberapa universitas yang melaksanakan $\mathrm{KKN}$ di wilayah tersebut. Hal ini menjadikan masyarakat cukup paham maksud dan tujuan program KKN. Sehingga mempermudah proses sosialisasi kepada masyarakat.

Adapun tim pelaksanaan KKN Universitas Ibn Khaldun 2017 terdiri dari 14 orang dengan berbagai latar belakang keilmuan yang diambil dari setiap fakultas dengan harapan semua bidang dapat berintegrasi untuk menciptakan programprogram yang sesuai dengan kebutuhan masyarakat.

Tema yang di ambil dalam kegiatan KKN tahun ini berkenaan dengan gerakan aliterasi di masyarakat sehingga fokus kegiatan pada peningkatan kesadaran dan pemahaman kepada masyarakat melalui bidang literasi baik itu dengan membentuk rumah baca maupun dengan penyuluhan. Dengan menyadarkan masyarakat terhadap pentingnya gerakan literasi ini diharapkan dapat meningkatkan taraf hidup masyarakat di bidang agama, pendidikan dan kesehatan.

\section{Keadaan Geografis}

Desa Waru Jaya merupakan salah satu Desa di Wilayah Kecamatan Parung Kabupaten Bogor, dengan luas wilayah 293 Ha yang terbagi dalam 3 dusun, 7
Rukun Warga (RW) dan 27 Rukun Tetangga (RT).

Batas wilayah desa Waru Jaya adalah sebagai berikut::

\begin{tabular}{|c|l|c|}
\hline No & Keterangan & Berbatasan \\
\hline 1 & Utara & $\begin{array}{c}\text { Desa Cidokom } \\
\text { Kecamatan Gunung } \\
\text { Sindur }\end{array}$ \\
\hline 2 & Selatan & $\begin{array}{c}\text { Desa Waru, dan Desa } \\
\text { Pamegarsari } \\
\text { Kecamatan } \\
\text { Parung }\end{array}$ \\
\hline 3 & Barat & $\begin{array}{c}\text { Iwul Kecamatan } \\
\text { Parung }\end{array}$ \\
\hline 4 & Timur & $\begin{array}{c}\text { Desa Bojong Sempu, } \\
\text { Desa Bojong Indah, } \\
\text { dan } \\
\text { Desa Cogreg } \\
\text { Kecamatan Parung }\end{array}$ \\
\hline
\end{tabular}

Pemanfaatan lahan/penggunaan tanah di Desa Waru Jaya adalah sebagai berikut:

\begin{tabular}{|c|l|c|}
\hline No & Keterangan & Luas (Ha) \\
\hline 1 & $\begin{array}{l}\text { Perumahan/pemukiman } \\
\text { dan pekarangan }\end{array}$ & 217 \\
\hline 2 & Sawah/ empang & 38 \\
\hline 3 & Lading/Huma & 21 \\
\hline 4 & Jalan & 5,1 \\
\hline 5 & Pemakaman/kuburan & 3 \\
\hline 6 & Perkantoran & 0,03 \\
\hline 7 & Lapangan olah raga & 7 \\
\hline 8 & $\begin{array}{l}\text { Tanah/ Bangunan } \\
\text { pendidikan }\end{array}$ & 5 \\
\hline 9 & $\begin{array}{l}\text { Tanah/ Bangunan } \\
\text { Peribadatan }\end{array}$ & 3,84 \\
\hline
\end{tabular}

Sedangkan Tanah Kas Desa seluas 19.106 Ha, penggunaannya sebagai berikut:

\begin{tabular}{|c|l|c|}
\hline No & Keterangan & Luas (Ha) \\
\hline 1 & Bangunan Kantor Desa & 0,03 \\
\hline 2 & $\begin{array}{l}\text { Bangunan SD/ SMP / } \\
\text { MI }\end{array}$ & 1,152 \\
\hline
\end{tabular}




\begin{tabular}{|c|l|c|}
\hline 3 & Tanah makam/ kuburan & 1,68 \\
\hline 4 & $\begin{array}{l}\text { Masjid / Musholla / } \\
\text { Majelis Ta'lim }\end{array}$ & 3,84 \\
\hline 5 & Jalan Desa & 5,1 \\
\hline 6 & Lapangan olahraga & 7 \\
\hline
\end{tabular}

\section{Kondisi Masyarakat}

Jumlah penduduk Desa Waru Jaya sampai akhir bulan Desember tahun 2013 tercatat sebanyak 12.539 jiwa Dengan kepadatan penduduk per/Km 0,001 Jiwa, terdiri dari:

\begin{tabular}{|c|l|c|}
\hline No & Jenis Kelamin & Jumlah \\
\hline 1 & Laki-laki & 6 \\
\hline 2 & Perempuan & 28 \\
\hline 3 & Jumlah KK & 2 \\
\hline
\end{tabular}

Keadaan mata pencaharian penduduk Desa Waru Jaya, adalah sebagai berikut:

\begin{tabular}{|c|l|c|}
\hline No & Pekerjaan & Jumlah \\
\hline 1 & Petani & 254 \\
\hline 2 & Tukang Bangunan & 47 \\
\hline 3 & PNS & 93 \\
\hline 4 & Polri / TNI & 8 \\
\hline 5 & Karyawan Pabrik & 321 \\
\hline 6 & Penjahit & 9 \\
\hline 7 & Pengrajin & 18 \\
\hline 8 & Tukang Las & 4 \\
\hline 9 & Tukang Ojeg & 121 \\
\hline 10 & Pedagang & 678 \\
\hline 11 & Pensiunan & 38 \\
\hline 12 & Peg. Swasta & 661 \\
\hline 13 & Bengkel & 6 \\
\hline 14 & Sopir & 36 \\
\hline
\end{tabular}

Permasalahan ekonomi yang terjadi di lingkungan RW 02 adalah maraknya praktek bank keliling atau dikenal di lingkungan tersebut sebagai bank berjanji. Ekonomi keluarga yang harusnya tumbuh dengan sokongan dana Menai lumpuh karena beban bunga yang ditanggung dan peruntukan yang tidak semestinya. Ketidakmampuan untuk membayar hutang menjadikan masyarakat harus menggadaikan atau menjual perabotan rumah untuk bisa membayar hutang.

Lingkungan RW 02 memiliki kegiatan usaha produksi kerudung sehingga banyak dari masyarakat yang menjadi buruh lepas dengan upah yang cukup murah. Sehingga masyarakat harus sibuk menghabiskan waktu untuk bisa mencapai upah yang diharapkan.

Adapun, Tingkat Pendidikan Penduduk Waru Jaya adalah sebagai berikut:

\begin{tabular}{|c|l|c|}
\hline No & Tingkat Pendidikan & Jumlah \\
\hline 1 & SD & 4.903 \\
\hline 2 & SMP & 1.307 \\
\hline 3 & SMA & 995 \\
\hline 4 & Akademik (D1-D3) & 221 \\
\hline 5 & Sarjana (S1-S3) & 175 \\
\hline 6 & Tidak Tamat SD & 840 \\
\hline & Di wilayah RW 02 terdapat 3
\end{tabular}

lembaga Pendidikan anak-anak yaitu PAUD Ceria, TPQ Al-Istiqomah dan Majelis Taklim Nurul Aliyah. Permasalahan yang di hadapi di bidang adalah kurangnya tenaga pengajar. TPQ Al-istiqomah dengan jumlah anak-anak yang belajar mencapai 60 orang namun hanya memiliki 3 orang guru. Bahkan di majelis taklim Nurul Aliyah hanya terdapat 1 guru untuk mengajar sekitar 40 orang. Begitu pula dengan PAUD Ceria yang kekurangan tenaga pengajar. PAUD Ceria yang merangkap Rumah Baca memang baru berjalan beberapa bulan saja. Sehingga masih membutuhkan banyak sosialisasi.

Masalah lainnya yaitu sarana dan prasarana yang belum mendukung secara penuh kegiatan belajar mengajar. Ruang belajar yang kurang representatif, meja 
belajar yang cukup usang serta papan tulis yang sudah tidak layak pakai.

Sedangkan jumlah tenaga medis yang ada dan melaksanakan praktek di Desa, adalah sebagai berikut:

\begin{tabular}{|c|l|c|}
\hline No & Keterangan & Jumlah \\
\hline 1 & Dokter Puskesmas & - \\
\hline 2 & Dokter praktek Swasta & - \\
\hline 3 & Bidan Desa & 1 \\
\hline 4 & Bidan Praktek Dewasa & 2 \\
\hline 5 & Dukun beranak terlatih & 3 \\
\hline 6 & $\begin{array}{l}\text { Dukun beranak tidak } \\
\text { terlatih }\end{array}$ & - \\
\hline 7 & Kader Posyandu & 50 \\
\hline
\end{tabular}

Permasalahan umum yang terjadi di beberapa wilayah kabupaten Bogor adalah sampah termasuk wilayah desa Waru Jaya Dusun II RW 02. Ketiadaan bak sampah atau TPS di wilayah tersebut membuang sampah di tempat yang bukan semestinya seperti selokan, sungai dan tanah kosong sepanjang jalan utama. Pemandangan sampah sudah bukan hal yang aneh lagi dan dikhawatirkan akan menjadi kebiasaan buruk di masyarakat.

Permasalahan lain yang muncul sebagai akibat dari tidak adanya pengelolaan sampah rumah tangga membuat masyarakat berinisiasi untuk membakar sampah yang di lingkungan rumah masing-masing. Dan sudah menjadi pengetahuan umum bahwa asap hasil pembakaran khususnya sampah plastik akan menyebabkan polusi udara yang berdampak pada kesehatan khususnya pernafasan. Ditambah dengan limbah kain perca dari industri kerudung menambah permasalahan kebersihan dan kesehatan.

Masalah lain yang ada yaitu adanya peternakan sapi di tengah-tengah pemukiman warga. Pengelolaan limbah kotoran yang tidak baik menjadikan lingkungan di sekitar kandang tercemar. Bau yang tidak sedap mengganggu kenyamanan masyarakat. Serta kotoran yang tersapu air hujan mengalir ke beberapa rumah warga yang posisinya lebih rendah.

\section{Kondisi sosial}

Secara umum kondisi sosial politik serta ketenteraman dan ketertiban di wilayah Desa Waru Jaya cukup baik dan terkendali. Dalam hal ini, kehidupan politik warga masyarakat dapat tersalurkan sesuai dengan aspirasinya seiring dengan bergulinya reformasi dan banyaknya partai politik yang berkembang pada saat ini.

Berkaitan dengan masalah keamanan dan ketertiban, dapat disampaikan bahwa pada tahun 2013, situasi, dan kondisi Desa Waru Jaya terbilang aman. Adapun gangguan keamanan, dan ketertiban yang terjadi pada tahun 2013 antara lain: pencurian sebanyak $7 \mathrm{x}$, penipuan ... $\mathrm{x}$, dan perampokan ... x.

Adapun jumlah anggota Perlindungan Masyarakat (Linmas) sampai saat ini tercatat sebanyak 10 orang, yang mendapatkan bantuan keuangan intensif oleh pemerintah Kabupaten Bogor. Kelembagaan Linmas pada saat ini sudah adanya di Pemerintah Kabupaten Bogor, Kantor Satuan Polisi Pamong Praja dan Linmas yang mengatur tentang keberadaan Linmas di Tingkat Kabupaten Bogor, sesuai dengan berubahnya Organisasi dan Tata Kerja Pemerintah Kabupaten Bogor. 


\section{METODE PENGABDIAN}

Tahapan pelaksanaan untuk kegiatan ini sebagaimana terlihat pada bagan sebagai berikut:

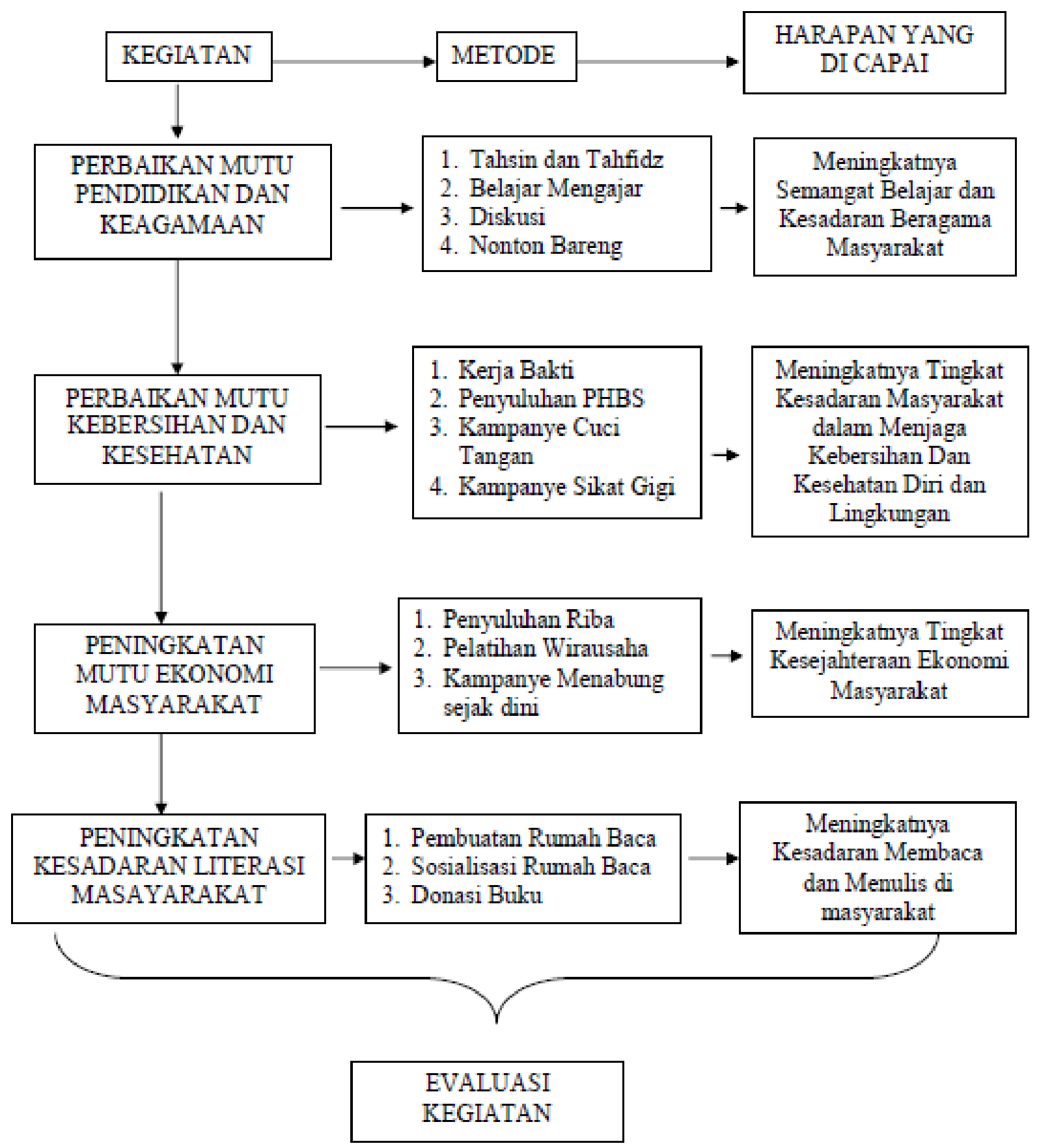




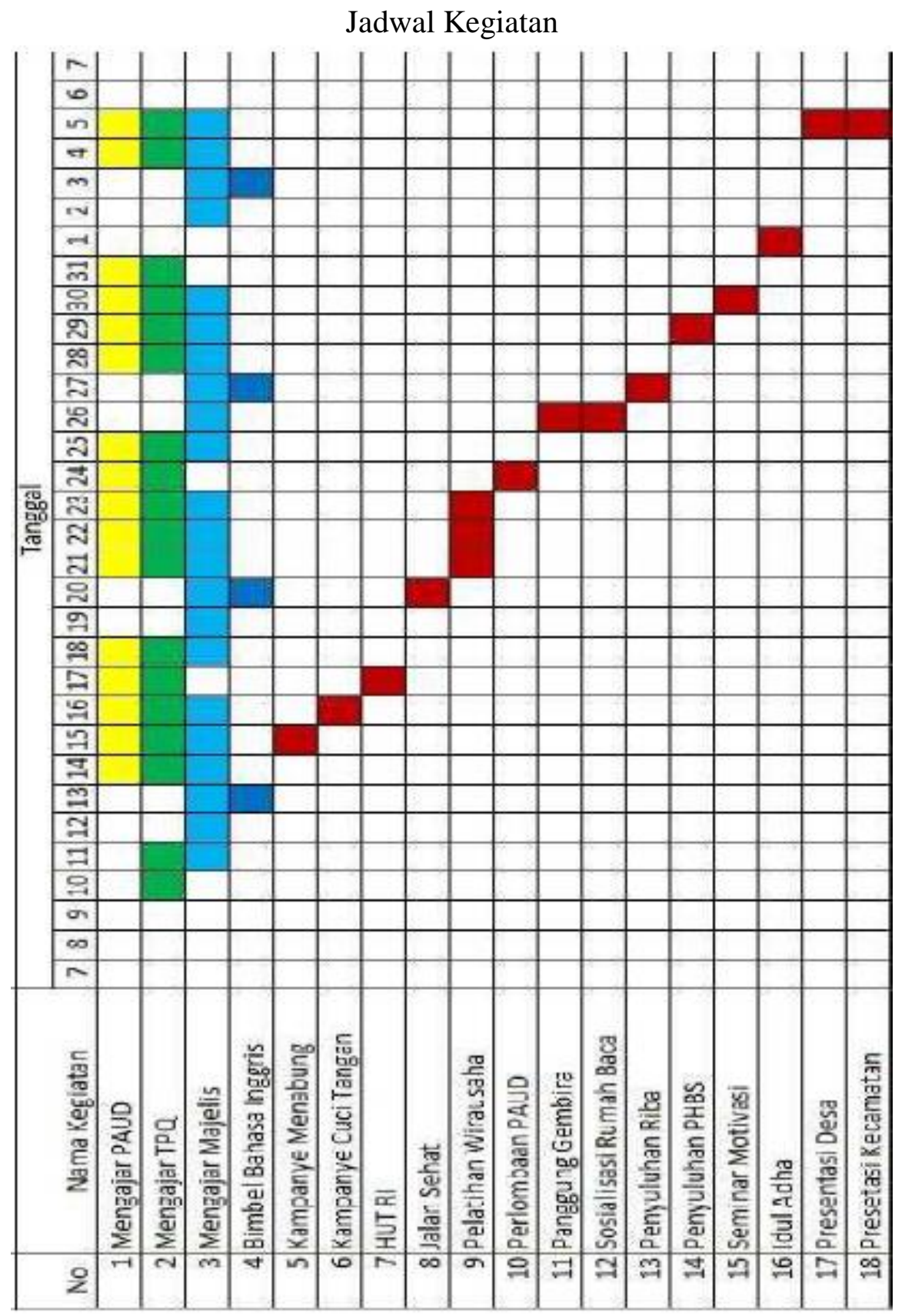

\section{Metode Pendekatan}

Pendekatan yang digunakan dalam kegiatan ini adalah:

1. Pendekatan organisasi, adalah pendekatan yang seluruh kegiatan yang diorganisir oleh RW, RT, IPPMI (Ikatan Pengajian Pemuda Masjid AlIstiqomah), dan ibu PKK yang memang mempunyai peran besar di dalam kegiatan di wilayah Desa Waru Jaya khususnya Kampung Waru Kaum.
Mulai dari silaturahmi ke para pemuka desa dan meminta bantuan kepada mereka sebagai jembatan untuk menghubungi para warganya, baik bapak-bapak dan ibu-ibu maupun pemuda pemudinya.

2. Pendekatan kekerabatan, yaitu pendekatan yang menjalin keakraban dengan selalu menghadiri pengajian bapak-bapak, majelis taklim ibu-ibu, 
dan TPQ anak-anak. Sehingga terciptanya keakraban dan kebersamaan melalui pendekatan tersebut.

3. Pendekatan individu, yaitu pendekatan yang memperhatikan faktor individu secara utuh meliputi, watak, intelegensi, psikologi dan kemampuan psikomotorik dengan mengajak bicara ibu-ibu dan bapakbapak sekitar, sehingga menimbulkan rasa solidaritas dan komunikasi yang baik antar individu.

\section{Partisipasi Masyarakat dalam Pelaksanaan Program}

Partisipasi masyarakat yang dapat dilakukan dalam kegiatan ini adalah sebagai berikut:

1. Mempersiapkan jama'ah jika ada penyuluhan atau pembuatan prakarya

2. Mempersilakan untuk menggunakan masjid, majelis, dan PAUD sebagai sarana untuk melaksanakan programprogram KKN

3. Selalu memberikan informasi terkait keadaan kampung dan warga yang memudahkan bagi mahasiswa untuk menggarap program yang telah direncanakan

4. Para pemuka kampung yang selalu memberikan kemudahan dan mempersilakan untuk membuat acara apapun asal tidak lepas koordinasi dengan pihak-pihak desa.

5. Pemuda pemudi yang turut serta ketika ada kegiatan $\mathrm{KKN}$

\section{Langkah Evaluasi}

Evaluasi yang akan dilakukan terdiri dari:

1. Evaluasi proses, yaitu evaluasi yang dilaksanakan sebelum melaksanakan kegiatan $\mathrm{KKN}$, evaluasi proses akan dilaksanakan setiap melakukan kegiatan
2. Evaluasi hasil, yaitu evaluasi yang dilakukan setelah melakukan kegiatan KKN, evaluasi hasil akan dilaksanakan setiap selesai melakukan agenda.

3. Evaluasi dampak, yaitu evaluasi yang dilaksanakan untuk melihat sejauh mana dampak program di masyarakat. Kegiatan dilakukan setelah program KKN selesai.

\section{REALISASI PROGRAM}

\section{Program Bidang Pendidikan}

a. Pendidikan Anak Usia Dini (PAUD)

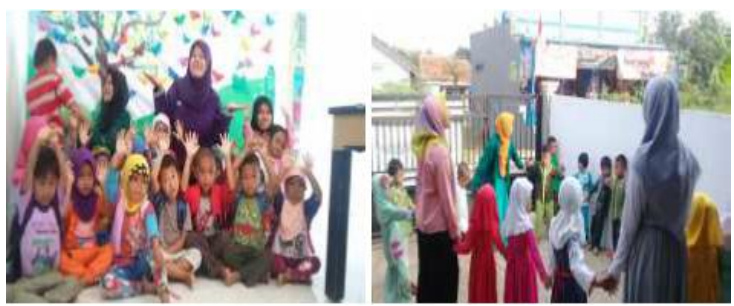

b. Mengajar TPQ Al-Istiqomah

c. Pengajian Anak-anak di Majelis Taklim Nurul Aliyah

d. Bimbingan Belajar Bahasa Inggris

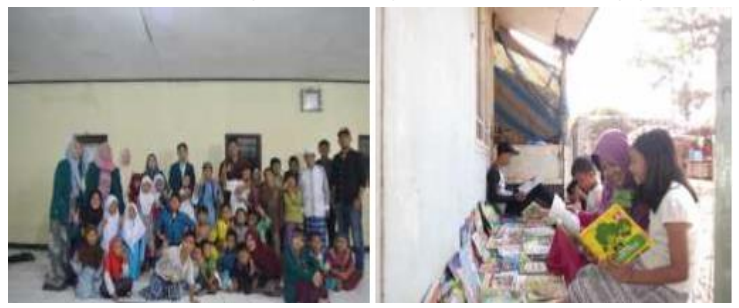

e. Rumah Baca Ceria

\section{Program Bidang Ekonomi}

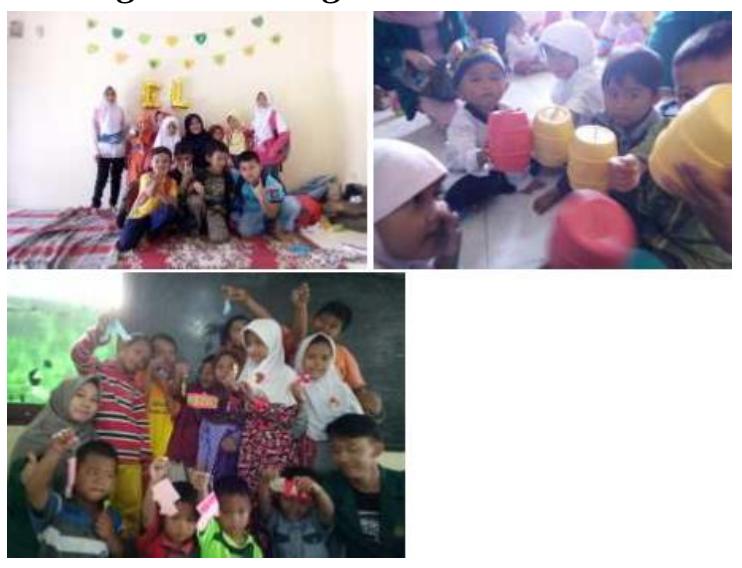

a. Kampanye Menabung Sejak Dini

b. Pelatihan Kewirausahaan 

c. Penyuluhan Riba
d. Seminar Motivasi

\section{Program Bidang Kesehatan}

a. Kampanye Cuci Tangan Pakai Sabun

b. Penyuluhan Sikat Gigi yang baik dan benar

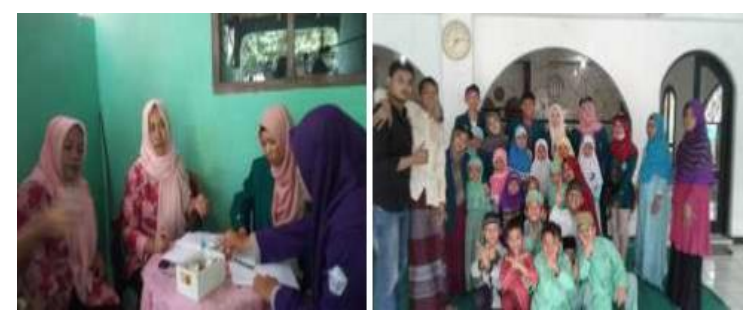

c. Penyuluhan PHBS

\section{Program Bidang Lingkungan}

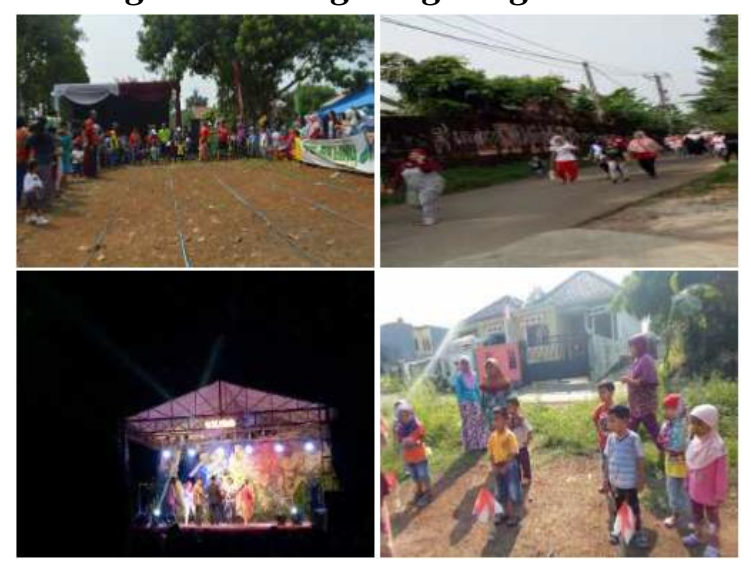

a. HUT RI

b. Pegelolaan Sampah

\section{KESIMPULAN}

Dari semua pemaparan diatas ada beberapa hal yang dapat disimpulkan sebagai hasil dari proses pelaksanaan kegiatan KKN UIKA terintegrasi 2017 diantaranya :

1. Proses KKN yang berlangsung selama 30 hari di wilayah RW 02 Dusun II desa Waru Jaya Kecamatan Parung.

2. Kegiatan KKN bertemakan gerakan literasi untul meningkatkan taraf hidup masyarakat dengan bidang tersebut.
3. Program kerja yang dijalankan disesuaikan dengan tema dan kebutuhan masyarakat untuk mendapatkan hasil yang diinginkan.

4. Adapun bidang yang di garap dalam kegiatan KKN kelompok 19 ialah: Pendidikan, Agama, Ekonomi, Kesehatan, kebersihan dan lingkungan secara umum.

5. Masyarakat wilayah KKN kelompok 19 berpartisipasi dalam pelaksanaan setiap program KKN.

6. Kegiatan yang dilaksanakan memiliki dampak positif terkhusus bagi anakanak didik dengan meningkatnya antusias belajar.

\section{Dampak Bagi Masyarkat}

Setelah melakukan kegiatan KKN Terintegrasi di Kp. Sindang Resmi Desa Tapos 1, masyarakat mendapakan beberapa dampak positif yang dihasilkan dari program-program yang telah kami laksanakan mulai dari mengajar di SDN Tenjolaya, Paud An-Naml dan Madrasah Diniyah Miftahul Falah kemudian kami juga mengajar BIMBEL. Dampak positif timbul karena dengan adanya programprogram tersebut dapat menumbuhkan minat belajar anak-anak kp. Sindang Resmi dalam memahami materi yang sekiranya kurang dipahami oleh mereka dan memotivasi mereka untuk sekolah kejenjang yang lebih tinggi.

\section{SARAN}

Kami rasakan kekurangan dan keterbatasan dalam setiap proses pelaksanaan kegiatan KKN ini. Banyak hal yang harus di perbaiki dan terus dikembangkan. Ada beberapa hal yang harus diperhatikan dalam pelaksanaan 
kegiatan KKN atau penelitian di masa yang akan datang diantaranya :

1. Tim pelaksana harus lebih banyak bersosialisasi dan berinteraksi dengan masyarakat untuk mendapatkan informasi yang lebih akurat.

2. Melanjutkan dan atau melaksanakan wacana pembangunan biogas untuk menangani masalah limbah peternakan di wilayah RW 02

\section{REFERENSI}

(2017) Pedoman Pelaporan PPM Uiversitas Ibn Khaldun Bogor, Bogor : LPPM UIKA

Bahari. (2010). Toleransi Beragama Mahasiswa (Studi tentang Pengaruh Kepribadian, Keterlibatan Organisasi, Hasil Belajar Pendidikan Agama, dan Lingkungan Pendidikan terhadap Toleransi Mahasiswa Berbeda Agama pada 7 Perguruan Tinggi Umum Negeri. Jakarta: Kementerian Agama RI Badan Litbang dan Diklat Puslitbang Kehidupan Keagamaan.

Damanhuri, E., dkk. 2004. Diktat Kuliah Pengelolaan Sampah. Edisi Semester I 2004/2005. Bandung: ITB.

ESP-USAID. 2010. Modul Pelatihan Pengelolaan Sampah Berbasis Masyarakat. Jakarta: Environmental Services Program.

Kusumadewi,L.R. (1999). Sikap dan Toleransi Beragama di Kalangan Mahasiswa: Studi di Tiga Perguruan Tinggi di Jakarta. Skripsi. Depok: FISIP UI.
Nuryanto, Heri, dkk. 2015. Kereta Anti Panik Sebagai Upaya Mewujudkan Pengelolaan Sampah Berbasis Masyarakat Di Desa Tanjungsekar Kecamatan Pucakwangi Kabupaten Pati.Semarang: Universitas Negeri Semarang.

Rachmawati, AFD. (2006). Toleransi Antar Umat Islam dan Katolik: Studi Kasus di Dukuh Kasaran, Desa Pasungan, Kecamatan Ceper, Kabupaten Klaten. Skripsi. Semarang: IAIN Walisongo.

Suparmini, dkk.2014. Pelatihan Pengelolaan Sampah Anorganik Menjadi Aneka Kreasi Daur Ulang Bagi Ibu Rumah Tangga Dan Remaja Putri Di Desa Trimulyo Kecamatan Jetis Kabupaten Bantul. Yogyakarta: Universitas Negeri Yogyakarta

Tim Penyusun. (2008). Toleransi dalam Pasungan: Pandangan Generasi Muda terhadap Masalah Kebangsaan, Pluralitas dan Kepemimpinan Nasional. Jakarta:SETARA Institute.

Tim Peneliti. (2006). Laporan Hasil Survei Pengetahuan, Sikap dan Perilaku Stakeholders terhadap Organisasi Masyarakat Sipil. Jakarta: LP3ES dan YAPPIKA. 